\title{
Income distribution in Croatia: what do the household budget survey data tell us?
}

Nestić, Danijel

Source / Izvornik: Occasional Paper Series, 2005, 9, 1 - 20

Journal article, Published version

Rad u časopisu, Objavljena verzija rada (izdavačev PDF)

https://doi.org/10.3326/ops.26

Permanent link / Trajna poveznica: https:/urn.nsk.hr/urn:nbn:hr:242:340723

Rights / Prava: Attribution-NonCommercial-NoDerivatives 4.0 International/ImenovanjeNekomercijalno-Bez prerada 4.0 međunarodna

Download date / Datum preuzimanja: 2023-04-26

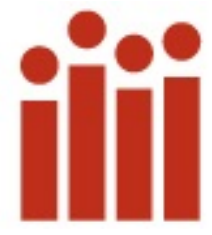

Institute of Public Finance Repository

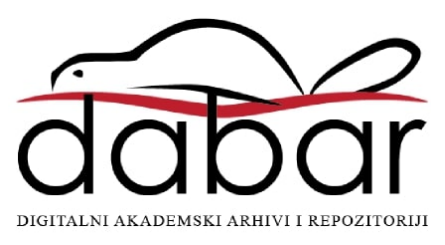




\section{INCOME DISTRIBUTION IN CROATIA: \\ WHAT DO THE HOUSEHOLD BUDGET \\ SURVEY DATA TELL US?}

Danijel Nestić

Occasional Paper No. 26

June 2005 


\title{
INCOME DISTRIBUTION IN CROATIA: WHAT DO THE HOUSEHOLD BUDGET SURVEY DATA TELL US?*
}

\author{
Danijel Nestić \\ The Institute of Economics, Zagreb \\ dnestic@eizg.hr
}

\begin{abstract}
The paper analyses income distribution in Croatia using the Household Budget Survey data. The results point to a mild increase in inequality during the 1998-2002 period. A non-linear increase in pensions in 2001 in favour of the better-off households has contributed to the rising inequality. In the meantime, other social transfers have become better targeted towards the poor suppressing overall inequality increase. Wages and salaries have become increasingly important and more unequally distributed sources of income. The income share of the poorest decile has shrunk due to its lower share in wages and pensions. The paper concludes with a proposal for introducing a panel survey of households in order to improve monitoring of poverty and inequality.
\end{abstract}

JEL Classification: D31

Key words: income distribution, inequality, Croatia

\footnotetext{
* This article is published in Croatian in the journal "Financijska teorija i praksa", 29(1), 2005, pp. 59-76, and is downloadable from: http://www.ijf.hr/financijska praksa/PDF-2005/1-05/nestic.pdf, and also in English from: http://www.ijf.hr/eng/finpraksa/PDF-2005/1-05/nestic.pdf.
} 


\section{TABLE OF CONTENTS}

1. Introduction 5

2. Household Budget Survey - basic data on income 5

3. Income composition and income inequality 8

4. Income distribution by decile groups 12

5. The distribution of income - how much the poorest receive 15

6. Conclusions 15

$\begin{array}{ll}\text { References } & 17\end{array}$ 


\title{
INCOME DISTRIBUTION IN CROATIA: WHAT DO THE HOUSEHOLD BUDGET SURVEY DATA TELL US?
}

\author{
Danijel Nestić
}

\section{INTRODUCTION}

Research on the distribution of income, especially that based on quantitative indicators, was highly neglected in Croatia right up until the end of the 1990s. Instead, judgements on income inequality were founded on a subjective feeling, or on simple statistical comparisons made by a few authors. One of the causes for this state of affairs was the absence of appropriate statistical data, primarily those relating to the distribution of total income and those capable of representing the whole population. However, in 1998 the Croatian Bureau of Statistics (CBS/DZS) started the regular administration of the Household Budget Survey, thus collecting information about overall income and various forms of household expenditure. This survey became the main source of information for calculations of inequality and poverty in Croatia (e.g, World Bank, 2000; Nestić, 2003; CBS, 2004).

The Household Budget Survey [the Survey] is a basically suitable and the only relevant source of data for the analysis of total income in Croatia. Hence this paper will show the basic features of the distribution of income in the 1998-2002 period. The distribution is analysed in terms of income per household member according to grouped CBS data on the distribution by deciles.

The paper is structured in the following way. After the introduction, Section 2 considers the basic statistical data about income that can be extracted from the Household Budget Survey. Section 3 shows changes in the structure of household income and presents calculations of income inequality. The contribution of individual components of income to total inequality is also derived, and attention is drawn to the trends in the last few years. The fourth part of the paper shows the main determinants of the distribution of incomes across decile groups. In Section 5, income shares of the poorest households regarding different types of income are considered, particularly those connected with government transfers. The sixth part contains a summary of the main findings and a proposal for the improvement of the statistical sources for the monitoring of inequality and poverty in Croatia.

\section{HOUSEHOLD BUDGET SURVEY - BASIC DATA ON INCOME}

This paper used the working tables of the CBS concerning the distribution of household income by decile group. The distribution is analysed in terms of the average income per household member in the 1998-2002 period analysed (DZS 1998; 1999; 2000; 2001; 2002). These data are not yet officially released, since the CBS prefers to publish data related to the distribution of total household income (DZS, 2003a), or the distribution of income per equivalent adult member (DZS, 2004). In this paper we slightly modify the scope of income as compared with the official statistical coverage so as to make income comparable over the whole of the period under observation or to make income definition more in line with international practice (e.g., financing items such as revenues from the sale of assets or loans 
are excluded from income aggregate). All the calculations are made upon the available grouped data, and not according to individual survey data. Irrespective of these modifications of original CBS data, we believe that the analysis based on them provide useful information concerning the main features of the distribution of income in Croatia.

Total household income is defined as the aggregate of all incomes from work, capital and government transfers, with the proviso that it includes incomes in kind, but not imputed housing rent. In that way, total income includes (i) net wages and benefits (transport, lunches); (ii), income from self-employment (from individual farming, trade or some other independent activity); (iii) pensions and other government transfers (unemployment, sick leave, children's benefits and welfare assistance); (iv) other monetary income (mainly property income); and ( $\mathrm{v}$ ) income in kind (payment in kind, the value of products from own land, garden or trade used). In order to assess the household well being more precisely, the total income of each household is divided by the number of members of the household, which provides the value of income per household member (income per capita). In other words, each household is characterised by amount of income per capita, and all the statistical data prepared and distribution analysis refer to income so defined.

Table 1, in the upper part, shows trends in average income per household member in the period 19982002 according to data from the Household Budget Survey (HBS). Average income per member rises in the whole of the period under observation (except in 2001) and in 2002 came to something over 21,000 kuna per year, or about 1,750 kuna per month. As against 1998, the average income per member was about $18 \%$ higher. However, if the rise in income is corrected by the rate of inflation (or, more accurately, by the rise in the cost of living index) then it appears that rise in real income was much less. Thus in 2002 the average income per household member was in real terms only slightly higher than in 1998. Oscillations in real income from year to year were important, with a particularly marked fall in 2001.

The trends in average income calculated according to the HBS differ notably from the trends of similar indices of well being taken from other data sources. The lower part of Table 1 gives data concerning changes of the level of real household consumption pursuant to data from the national accounts that are used in the calculation of GDP. Although the aggregate of consumption is different from that of income, it can be expected that during a period of several years we can observe similar trends in both aggregates. However, household consumption according to data from the national accounts shows a constant rise after 1999, while the average real income calculated from the HBS shows major oscillations and a much lower level in comparison with 1998 than is the case with consumption. The fact that in one case the total (consumption) is being considered, and in the other in an average (income) should not have significant influence on the result, considering the stability of the population size in Croatia during the past few years. 
Table 1 Household income 1998-2002

\begin{tabular}{|c|c|c|c|c|c|}
\hline & 1998 & 1999 & 2000 & 2001 & 2002 \\
\hline \multicolumn{6}{|l|}{ Household income (HBS) } \\
\hline Average income per member, per year (kuna) & 18,085 & 19,585 & 21,403 & 20,384 & 21,294 \\
\hline Nominal income per member $(1998=100)$ & 100.0 & 108.3 & 118.3 & 112.7 & 117.7 \\
\hline Real income per member $(1998=100)$ & 100.0 & 104.6 & 108.6 & 98.7 & 101.2 \\
\hline \multicolumn{6}{|l|}{ Other indicators of well being } \\
\hline Volume/scope of real household consumption $(1998=100)$ & 100.0 & 97.1 & 101.2 & 105.8 & 112.8 \\
\hline Average real net wage $(1998=100)$ & 100.0 & 110.1 & 113.9 & 115.7 & 119.2 \\
\hline
\end{tabular}

Note: Household income in the HBS does not include imputed housing rent. The scope of income is slightly modified as compared with the official scope used by the CBS so as to make the data comparable in the whole of the period under observation.

Source: Author's estimates based on SZS (1990) and DZS (1998; 1999; 2000; 2001; 2002; 2003b).

Experience from many other countries shows that data from household budget and expenditure surveys display a substantially lower rise in income and expenditure than data from the national accounts, particularly in developing countries, so that the difference noted for Croatia is not untypical. Often such a difference is attributed to the evasion of answers concerning incomes from the grey economy, the underreporting of consumption that is not considered socially acceptable (alcohol, tobacco, betting) or failure to comprehend the highest incomes, which often rise the fastest in the take-off phase of developing countries.

The trend in income calculated on the basis of the HBS can be compared with the trend in a similar indicator - average real net wages, the indices of which are shown in the bottom part of Table 1. Wages constitute the major part of total income, so that it is to be expected that there will be a high degree of correlation with the trend in overall income. However, the average real wage, according to CBS statistics from establishment surveys, shows a very dynamic year-by-year rise. In 2002 it was $20 \%$ higher than in 1998, while at the same time data about real income according to the HBS showed a level almost unchanged from 1998. The fact that in the meantime there was a slight fall in employment in legal entities (enterprises), of about 1\%, does not have any substantial impact on the discrepancies in the trends observed.

How can such different results be explained? First of all, it could be mentioned that the HBS was carried out in a time when it was objectively difficult to ensure a high degree of representativeness because of uncertainties related to the size of population. At the end of the 1990s, when the first surveys were administered, the population data necessary for suitable sampling procedure could only be found in the censuses of 1991. Unfortunately, that census could hardly provide an accurate picture of the population in late 1990s considering the turbulent times and great migrations of population. The sample frame for the first surveys, those of 1998 and 1999, was based on the census of 1991, but supplemented with a separate, specially designed, pre-census of occupied dwellings in selected areas. In 2000 a change occurred in the sample frame for the HBS, which was that year and on the following years based on the register of the Croatian Electricity Company about electricity meters. Since almost all households in Croatia are supplied with electricity, it was considered that this register could be used as the frame for the selection of the sample. From 2002 onwards the sample frame has been based on the 2001 census. Apart from changes in the sample frame, during the period in which the survey was carried out there 
were changes in the questionnaires, as well as in the calculation of the statistical weights. Then the very nature of the sampling in the HBS, where the sample of private households in each year is separately defined (i.e., there is no overlap in the sample from year to year), increases the instability of the results if they are observed year by year.

It can be estimated that the actual design of the HBS, along with the changes in the sample frame tended to result in certain limitations on the comparability of income levels year by year. And so the sequel this paper will be much more directed to the structural indicators that can be assumed to have been less affected by the problems of temporal comparability of levels. Similarly, for the sake of easier spotting of trends, the rest of the paper will consider data for each other (even) year, for 1998, 2000 and 2002, and compared with the situation in pre-transitional $1988 .^{1}$

\section{INCOME COMPOSITION AND INCOME INEQUALITY}

Changes in the structure of household income in Croatia reflect fairly well a time of vigorous economic changes in the last fifteen years, which can be seen from the data presented in Table 2. Just before the beginning of the transition, 1988, wages made up about $55 \%$ of total household income; pensions, and other government transfers made up 14\%; while income from self-employed work and income in kind made up $12 \%$ of total income. Ten years later wages made up a much smaller part of total income; a fall of ten percentage points having occurred. At the same time the proportion of pensions and social transfers had increased by the same amount. Such trends in the1988-1998 period can be linked with a reduction in the rate of employment, the ageing of the population and the increase in the pension and welfare rights related to the Homeland War. The welfare role of the state clearly remained very strong even after the collapse of the socialist system, with the proviso that it was shifted from the labour market (that is, from the maintenance of over-employment in the socialist firms) to the sphere of retirement and social policy. Income in kind as proportion of total income was reduced, which is an expected consequence of the strengthening of the market economy. And the increase in the proportion of income from self-employment by about 3 percentage points could be attributed to the same cause.

Table 2 Income composition and income inequality

\begin{tabular}{|c|c|c|c|c|}
\hline & 1988 & 1998 & 2000 & 2002 \\
\hline \multicolumn{5}{|l|}{ Household income (share in \%) } \\
\hline Wages & 55.1 & 45.3 & 51.2 & 50.6 \\
\hline Self-employment income & 11.5 & 14.5 & 12.5 & 13.7 \\
\hline Pensions and government transfers & 13.9 & 24.0 & 24.5 & 27.4 \\
\hline Other monetary income & 7.6 & 8.7 & 6.7 & 3.7 \\
\hline Income in kind & 11.9 & 7.5 & 5.1 & 4.7 \\
\hline \multicolumn{5}{|l|}{ Inequality indices } \\
\hline Gini coefficient & 0.276 & 0.290 & 0.298 & 0.298 \\
\hline Theil entropy index & 0.137 & 0.146 & 0.156 & 0.154 \\
\hline Decile ratio d9/d1 & - & 3.64 & 4.01 & 4.09 \\
\hline
\end{tabular}

\footnotetext{
${ }^{1}$ This decision is made also because of the lack of appropriate information about distribution of income per member of the household for 1999 .
} 
Note: The distribution of income per member of the household is considered. Income does not include imputed housing rent. Definition and classification of income is slightly modified from what is officially used by the CBS so that the data should be comparable in the period under observation. Income from self-employment includes money income of individual farmers, craftsmen and free-lances, while the value of consumption of goods from own land is included in income in kind. See more about the scope of income in the text (Chapter 2).

Source: Author's estimates based on SZS (1990) and DZS (1998; 2000; 2002).

From 1998 to 2002 a rise in the income share of wages was noticeable, as well as a further rise in the income share of pensions. This could be related to the progress in the transition towards market economy where work efforts are rewarded more strongly than in previous socialist economy. However, income from self-employment did not increase its share, but in 2002 amounted to a smaller proportion than in 1998. This can be attributed to a decline in small individual farming, but also to the increased competition that unincorporated sector had to meet, both from imports and from the domestic sector of firms. The rise in the share of pensions, particularly between 2000 and 2003 is mostly to be connected with the rise in pensions in 2001 according to the Increase in Pensions for the Sake of Obviating Differences in the Level of Pensions Disbursed in Different Periods Law (NN 127/00). The proportion of in-kind income in total income continued to fall, which is in accordance with the strengthening of the market economy.

According to available figures concerning the distribution of income per household member several inequality indicators were estimated. ${ }^{2}$ The results are shown in the bottom half of Table 2. The Gini coefficient points to moderate growth of inequality between 1988 and 1998 , from 0.28 to 0.29 , which is something of a surprise, for a much greater growth in inequality had been expected during the decadelong transition period. However, the welfare role of the state had also increased, particularly in the domain of pensions via the opportunities for early retirement, and the maintenance of relatively high employment in the public sector in which a moderate inequality in the distribution of wages was maintained. These factors might explain the slight rise in inequality in the distribution of overall income. From 1998 to 2002 there was a further moderate rise in inequality as measured by the Gini coefficient, from 0.29 to 0.30 . The Theil entropy index and the $d 9 / d 1$ decile ratio show similar tendencies in the trends in inequality. ${ }^{3}$ They also suggest a slight rise in inequality between 1998 and 2002.

Income structure and inequality in distribution within individual components (sources) of income are important determinants of inequality of total income. One of the ways of estimating the contribution of given income components to total inequality is the decomposition of the Gini coefficient according to the method proposed by Fei, Ranis and Kuo (1978). Thus inequality measured by the Gini coefficient can be expressed as a weighted average of Gini coefficients of concentration of the individual components, where the shares of each component of income in the total income are used as weights:

$G=\sum_{k=1}^{K} \frac{\mu_{k}}{\mu} G_{k}^{*}=\sum_{k=1}^{K} \lambda_{k} G_{k}^{*}$

\footnotetext{
${ }^{2}$ On the calculation of standard inequality indicators such as the Gini coefficient and the Theil entropy index, see e.g. Cowell (1995).

${ }^{3}$ The decile ratio $d 9 / d 1$ is defined as the ratio of the income of the poorest persons among the $10 \%$ of the richest people and the income of the richest person in the group of the $10 \%$ of the poorest people.
} 
Here $G$ stands for the Gini coefficient, $G_{k}{ }^{*}$ is the Gini coefficient of concentration for the $c$ 's component of income, $\mu_{k}$ is the average of the c's component, and $\mu$ is the average of total income, with $\lambda_{k}=\mu_{k} / \mu$. The Gini coefficient of concentration is an indicator similar to the original Gini coefficient, except that in the calculation of it the population is ordered according to total income, and not according to the individual component for which the coefficient is being calculated. The coefficient of concentration captures both an internal inequality in the distribution of a given kind of income, and the correlation of it with total income. This coefficient can take on values from -1, when the whole amount of the given income component is received by the poorest person in the distribution of total income, to 1 , when the entire amount is received by the overall richest person. The relative contribution of the $c$ component of income to the total inequality $\left(s_{k}\right)$ is calculated as:

$s_{k}=\frac{\lambda_{k} G_{k}^{*}}{G}, \quad \sum_{k=1}^{K} s_{k}=1$

In other words, for an estimation of the relative contribution of each component of income to total inequality what is important is; (i) its share in total income, and (ii) its coefficient of concentration. Since the coefficient of concentration can take on values from -1 to 1 , the relative contribution of an individual component can be positive or negative. A positive sign of the relative contribution of the $c$ component of income indicates a situation in which a distribution of that component contributes to an increase in inequality of total income. Or, if the $c$ component of income, instead of the existing distribution, were equally distributed among households, ceteris paribus, then the inequality in the distribution of total income would be lower. Thus the fact that the $c$ component of income is distributed in the existing manner, and not equally, has contributed to increased inequality. And vice versa, the negative relative contribution indicates a situation in which the component of income contributes to a reduction of total inequality. In an equal distribution of such a component of income instead of the existing distribution, in conjunction with an unchanged distribution in the other income components, there would be an increase in overall inequality. This would mean that the existing distribution of the component of income, as compared with the situation in which it was equally distributed, goes to a reduction in overall inequality. The relative contributions of all components of total income are summed in one.

The results of this decomposition for Croatia for 1998, 2000 and 2002 are shown in Table 3. In all three years, wages made the greatest contribution to total inequality, because of the high proportion of overall income that they constitute, and also because of a coefficient of concentration of wages which was somewhat higher than the Gini coefficient for total income (which can be seen in a comparison with data in Table 2). The concentration of wages in households with higher total incomes was increased in 2000 and 2002, as compared with 1998, which, together with an increase in the proportion that wages accounted for in total income, led to an increase in the contribution of wages to total inequality. In 2002, inequality in distribution of wages "explains" more than $60 \%$ of the inequality in the distribution of overall income. The contribution of income from self-employment however moved in the opposite direction. From 1998 to 2002 the concentration of income from self-employment was markedly reduced. This made the distribution of these incomes much more like the distribution of the wages of employed 
persons. Apart from that, the share of income from self-employment declined, so that the contribution of this income component to overall inequality was considerably reduced.

The contribution made by pensions to total inequality increased between 2000 and 2002, because of the increased concentration of pensions among the richer households, and because of the increased income share of pensions. Inequality in the distribution of pensions in 2002 explained more than $16 \%$ of overall inequality, which is double the amount of two years earlier. Such a change can primarily be explained by the non-linear increase in pensions in 2001 pursuant to the Increase in Pensions for the Sake of Obviating Differences in the Level of Pensions Disbursed in Different Periods Law (NN 127/00), by which the Government wanted to implement the Constitutional Court Decision concerning the socalled "debt to pensioners". ${ }^{4}$

Table 3 Contribution to total inequality by income components (decomposition of the Gini coefficient)

\begin{tabular}{|l|r|r|r|r|r|r|}
\hline & \multicolumn{2}{|c|}{1998} & \multicolumn{2}{|c|}{2000} & \multicolumn{2}{|c|}{2002} \\
\cline { 2 - 7 } & $\begin{array}{r}\text { Coefficient of } \\
\text { concentration }\end{array}$ & $\begin{array}{r}\text { Contribution to } \\
\text { total inequality } \\
(\%)\end{array}$ & $\begin{array}{r}\text { Coefficient of } \\
\text { concentration }\end{array}$ & $\begin{array}{r}\text { Contribution to } \\
\text { total inequality } \\
\text { (\%) }\end{array}$ & $\begin{array}{r}\text { Coefficient of } \\
\text { concentration }\end{array}$ & $\begin{array}{r}\text { Contribution to } \\
\text { total inequality } \\
\text { (\%) }\end{array}$ \\
\hline $\begin{array}{l}\text { Wages } \\
\text { Income from self- } \\
\text { employment }\end{array}$ & 0.306 & 48.8 & 0.361 & 63.2 & 0.367 & 63.5 \\
$\begin{array}{l}\text { Pensions } \\
\text { Social transfers } \\
\text { (without pensions) }\end{array}$ & 0.552 & 28.1 & 0.366 & 15.7 & 0.331 & 15.4 \\
$\begin{array}{l}\text { Other monetary } \\
\text { income }\end{array}$ & 0.120 & 8.3 & 0.112 & 8.1 & 0.206 & 16.5 \\
Income in kind & -0.001 & 0.0 & -0.047 & -0.5 & -0.151 & -2.1 \\
\hline
\end{tabular}

Source: Author's estimate based on DZS (1998; 2000; 2002).

The rise in pensions was unequal. Pensions that were taken up to 1995 were increased the most (up to $20 \%$ ), while pensions taken after that were as a rule increased by a smaller amount. The pensions rise was related to basic pensions. However, the existence of the minimum pension regulation, where the amount of minimum pension did not change, resulted in the total receipts of many pensioners, those with the lowest basic pensions, not rising at all. For if the basic pension was lower than the minimum the pensioner would receive a supplement up to the level of the minimum pension. In a situation in which the basic pension was increased in line with the Law, it would happen that the amount of the pension after the increase was still lower than the minimum pension, meaning that the total receipts of these pensioners did not change - they still received a sum amounting to the minimum pension. Furthermore, in this increase in pensions persons in receipt of pensions pursuant to the individual farmers insurance were not included at all, and it is this category of pensioners that has exceptionally low pensions. For this reasons it follows that pensioners with the lowest pensions continued to have no increase in their receipts, while the increase in receipts was unequally distributed among pensioners with higher pensions. A considerably enlarged coefficient of concentration of pensions in 2002 clearly shows that the repayment of the debt to pensioners led to an increase in the inequality of pensions, favouring

\footnotetext{
${ }^{4}$ Actually, the Law specifically alludes to this in Article 1: "This Law governs the manner of raising pensions for the sake of obviating differences in pensions acquired in various periods and it also executes the Decision of the Constitutional Court of the Republic of Croatia of May 121998 in accordance with the economic capacities of the Republic of Croatia" (NN 127/00).
} 
thereby better off households. Thereby, distribution of pension contributed to an increase in total inequality. ${ }^{5}$

Welfare transfers (benefits for unemployment, sick leave and dependent children and welfare benefits) usually tended to reduce total inequality. They are dominantly concentrated in the worst-off households, which is suggested by the negative coefficient of concentration of social transfers seen in Table 3 . What is more, concentration of these transfers amongst the poorest households increased in the 1998-2002 period. However, a relatively small contribution to the reduction of overall inequality of $2 \%$ in 2002 can be ascribed to the small share of such transfers in the total income. Thus social transfers (without pensions) in 2002 made up 4\% of the total income of a household, and in 1998 4.3\%. In such a situation an increase in the amount of social transfers could have a fairly effective impact on the reduction of overall inequality, because these transfers are quite well targeted towards the poorest households.

The contribution of the distribution of other monetary income (mostly incomes from property) to total inequality fell in the 1998-2002 period, primarily because of the reduction in such income as proportion of overall income, while the concentration of this kind of income in the period remained stable. The same thing goes for in-kind income, the proportion of which in overall income fell, and hence its effect on overall inequality was also reduced.

\section{INCOME DISTRIBUTION BY DECILE GROUPS}

An additional insight into the distribution of income is given by a comparison of income shares of various decile groups. Figure 1 shows a comparison of the decile shares in total income in 1998 and 2002. The comparison proves that the decile groups in the bottom part of the distribution in 2002 had a smaller share than in 1998, while there was an increase in the income share of the decile groups in the upper end, with the exception of the final decile. This is one more illustration of the increase in inequality that occurred in the period under observation. Thus the share of the first decile group (which covers the 10\% of the poorest households according to the income per household member criterion) fell from 3.5 to $3.1 \%{ }^{6}$ Similarly, the income shares of the second and third deciles fell. Ten percent of the richest households in Croatia had received about $23 \%$ of the total income. This share was the same in 2002 and 1998.

Sources of income are different for the households in the lower part of the income distribution (households with lower incomes) and households in the upper part of the distribution (households with higher incomes). Table 4 illustrates this with a portrayal of the structure of income per decile group in 2002. For the first decile, that is, for the poorest $10 \%$ of households, pensions were the major source of income, accounting for about $26 \%$. Wages account for about $25 \%$ of total income. Social transfers (without pensions) account for a substantial proportion of the incomes of the first decile, about $20 \%$, and in-kind income also has a significant share, of about $10 \%$. Wages in general are a dominant source of

\footnotetext{
${ }^{5}$ It should not, however, be neglected that pensions of most pensioners were actually increased, that is, that there was substantial rise in the average pension. This can be seen as the increased proportion of pensions and other social transfers in total income household in Table 2.

${ }^{6}$ It should be mentioned in the date we used the decile groups were already formed by CBS. Each decile group covers ten percent of the households surveyed ordered according to amounts of income per member, although it would be methodologically more correct if the groups had been formed so as to retain ten percent each of the estimated size of the population.
} 
income for all deciles, with the proviso that in the incomes of higher deciles as a rule wages come to a higher proportion of total income. In the last two decile groups, wages constituted $57 \%$ of total income.

Figure 1 Income share by deciles in 1998 and 2002 (in \%)

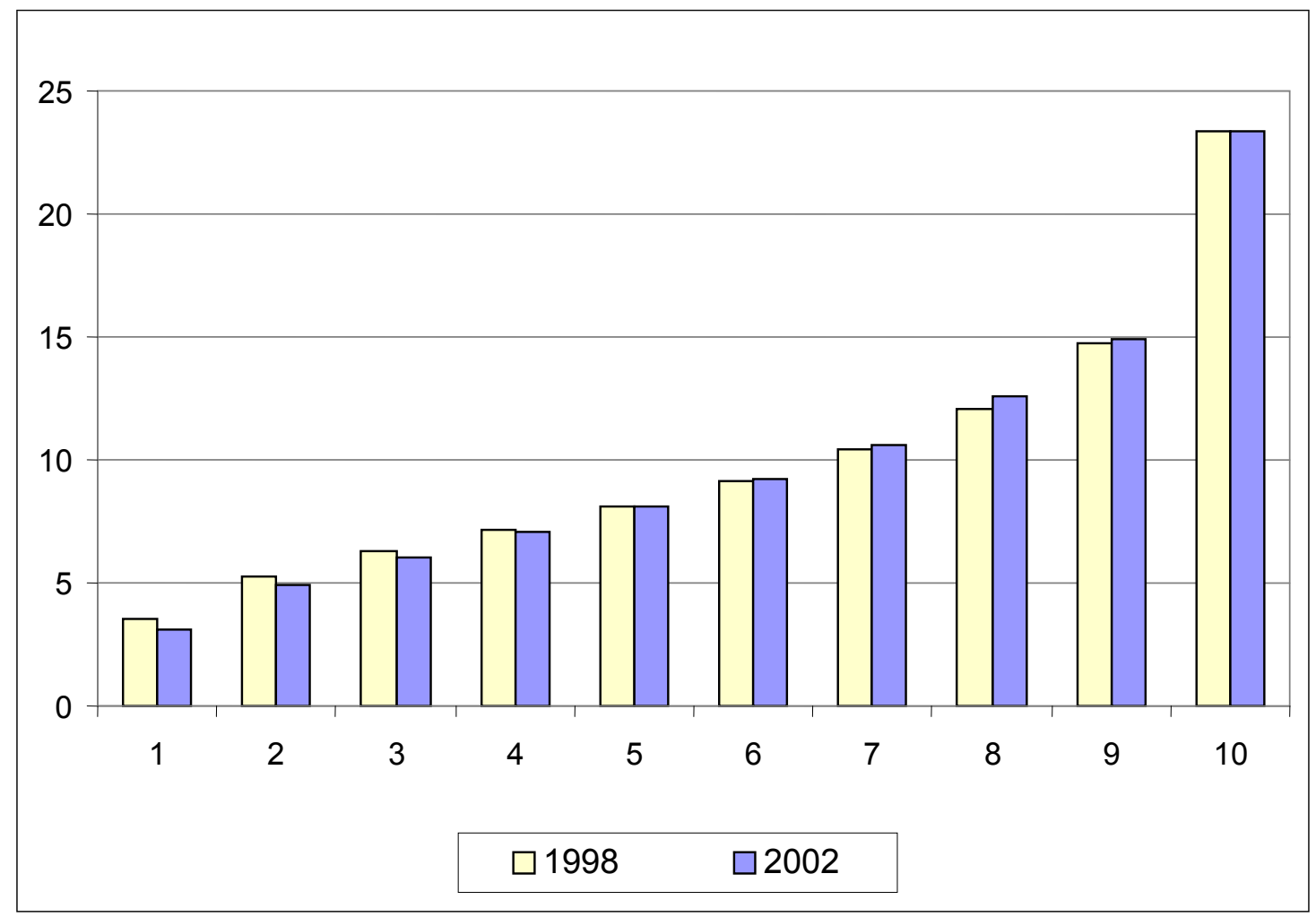

Source: Author's estimate based on DZS (1998; 2002).

Table 4 Income composition by decile group, 2002

\begin{tabular}{|l|r|r|r|r|r|r|r|}
\hline Decile & Wages & $\begin{array}{r}\text { Income from } \\
\text { self-employment }\end{array}$ & Pensions & $\begin{array}{r}\text { Other social } \\
\text { transfers }\end{array}$ & $\begin{array}{r}\text { Other monetary } \\
\text { income }\end{array}$ & $\begin{array}{r}\text { Income in } \\
\text { kind }\end{array}$ & $\begin{array}{r}\text { Total } \\
\text { income }\end{array}$ \\
\hline 1 & 25.3 & 15.4 & 26.1 & 20.2 & 3.3 & 9.7 & 100.0 \\
2 & 37.5 & 13.7 & 28.0 & 9.4 & 3.8 & 7.6 & 100.0 \\
3 & 44.0 & 12.5 & 26.3 & 7.1 & 3.7 & 6.4 & 100.0 \\
4 & 44.6 & 13.7 & 27.6 & 5.7 & 2.4 & 6.0 & 100.0 \\
5 & 47.6 & 12.7 & 27.4 & 4.7 & 2.2 & 5.4 & 100.0 \\
6 & 49.9 & 10.9 & 28.1 & 2.9 & 2.8 & 5.5 & 100.0 \\
7 & 54.6 & 11.0 & 24.1 & 2.7 & 2.8 & 4.8 & 100.0 \\
8 & 51.4 & 13.0 & 25.2 & 3.4 & 2.6 & 4.4 & 100.0 \\
9 & 57.4 & 11.7 & 22.4 & 1.5 & 3.7 & 3.4 & 100.0 \\
10 & 57.3 & 19.0 & 13.9 & 1.0 & 6.7 & 2.2 & 100.0 \\
\hline
\end{tabular}

Note: Income does not include imputed housing rent. The distribution of income per member of household is considered. Source: Author's estimation based on HBS (1988; 1999; 2000 and 2002).

Income from self-employment has a relatively high importance in the first and last deciles. However, the nature of such income is essentially different in these two deciles. While in the first decile it is mainly a matter of income from small individual farming, income from a trade (a free-lance occupation) is dominant in the tenth decile. In all the deciles the income share of pensions is on the whole the same constituting as a rule a bit over a quarter of total income, except in the last two deciles, where this 
percentage is smaller. The reduction in the share of pensions in the last decile is particularly apparent, for it comes to about $14 \%$. Other social transfers (unemployment, sick leave, home nursing benefits, child benefits, welfare assistance) are of some importance only in the poorest households, while in the other parts of the distribution they are an almost negligible source of income. Other monetary income (mainly property income) constitutes a stable $3 \%$ of total income in all deciles, except in the tenth, where the proportion of it in total income is a bit higher, about $7 \%$. Incomes in kind, mainly the value of goods from own farm, yard or trade used, are represented more strongly in the poorer households.

Figure 2 Aggregate shares of market income by deciles, 2002 (in \%)

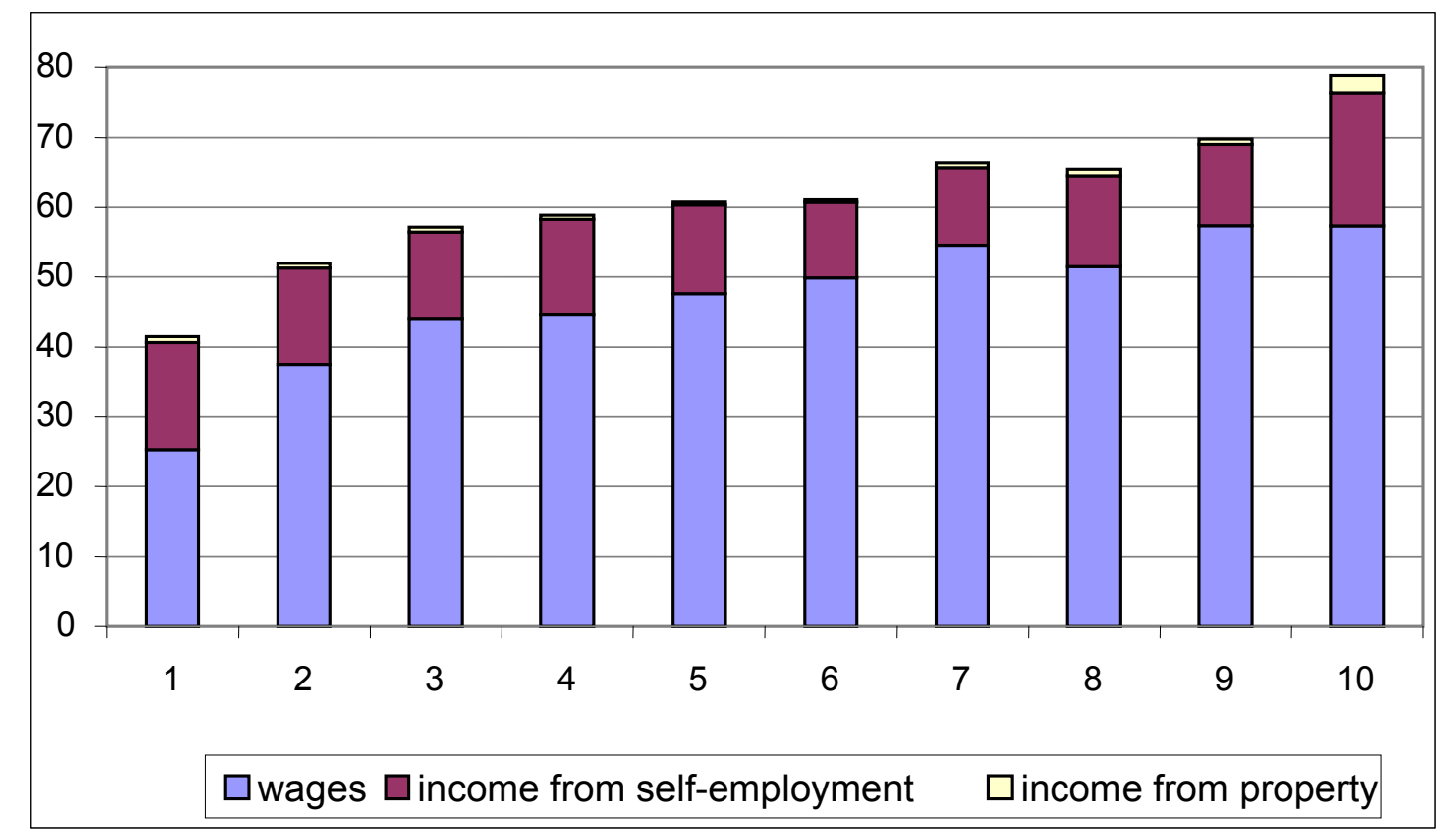

Note: Market income includes wages, self-employment income and property income.

Source: Author's estimate based on DZS (2002).

According to this kind of structure of income per decile group it is already possible to observe that the incomes of the richer households are to a much higher extent dependent on the market activity. This is confirmed by Figure 2. If we define wages, income from self-employment and income from property as market incomes, then it follows that in the poorest decile, it amounts to less than a half of their total income. It has already been mentioned that the poorest households to a very great extent rely on government transfers and income in kind. Market income, as a proportion of total income is larger in the higher deciles (i.e., in households with higher incomes). The richest $10 \%$ of households obtain almost $80 \%$ of their income directly on the market. Hence it can be concluded that participation in the market (above all the labour market), i.e., the opportunity to find employment, and hence the ability to generate income from work, is extremely important for an improvement of the material position of the poorest households. 


\section{THE DISTRIBUTION OF INCOME - HOW MUCH THE POOREST RECEIVE}

It has already been shown that there are differences in the sources of income between the richest and the poorest groups. It is desirable to consider the shares of the poorest households in given kinds of income, primarily in social transfers, so as to obtain an insight into the targeting of given forms of income towards the poorer households.

It can be seen from the figures in Table 5 that the poorest $10 \%$ of households are taking part less and less in the distribution of overall social transfers - their share has reduced from $6.2 \%$ in 1998 to $5.4 \%$ in 2002. This holds too if the poorest quintile is considered. The trend observed was nevertheless dominantly impacted by the distribution of pensions, with the poorest in recent years obtaining an eversmaller share. In 2002 the poorest $10 \%$ of households received $3.5 \%$ of the sum total of pensions. At the same time the degree of targeting of other social transfers rose. While in 1998 the poorest decile obtained $12 \%$ of social transfers not including pensions, in 2002 this proportion rose to about $17 \%$. The poorest quintile of the population received about $30 \%$ of all social transfers not including pensions in 2002.

Table 5 Income shares of the poorest households (\%)

\begin{tabular}{|l|r|r|r|r|r|r|}
\hline & \multicolumn{3}{|c|}{ Poorest 10\% } & \multicolumn{3}{c|}{ Poorest 20\% } \\
\hline & 1998 & 2000 & 2002 & 1998 & 2000 & 2002 \\
\hline Share in total social transfers & 6.2 & 5.7 & 5.4 & 15.3 & 13.2 & 12.3 \\
Share in total pensions & 5.0 & 4.6 & 3.5 & 13.8 & 11.2 & 9.6 \\
Share in other social transfers & 12.0 & 13.2 & 16.8 & 22.6 & 26.1 & 29.2 \\
Share in total wage bill & & & & & & \\
Share in total income & 2.3 & 2.0 & 1.5 & 6.5 & 6.2 & 5.2 \\
\hline
\end{tabular}

Note: Other social transfers include welfare benefits, unemployment benefits and government transfers related to children and the family.

Source: Author's estimates based on CBS (1998; 2000; 2002).

It has already been shown that a greater share of market income is associated with a higher level of total household income. It would seem that in this segment an ever-increasing exclusion of the poor is occurring. The share of poor households in the distribution of wages has fallen. In 2002 the poorest $10 \%$ of households received only $1.5 \%$ of total wages (as compared with $6.5 \%$ in 1998). Declining wage share of the poorest households was caused that their share in total income is also falling. In consequence, income inequality in the 1998-2002 period was increased, as already indicated via a number of aggregate measures of inequality.

\section{CONCLUSIONS}

The results of the examination of the income distribution on the basis of the Household Budget Survey in the 1998-2002 period can be summed up in a few findings: (i) the inequality in the distribution of overall income is slightly on the rise; (ii) wages are becoming an increasingly important source of income, and at the same time they are being increasingly concentrated in the richer households; (iii) the non-linear increase in pensions in 2001 (paying back the debt to the retirees) contributed to an increase in 
inequality; (iv) the targeting of social transfers to the poorer households has been increased, which has prevented an even greater rise in inequality and $(\mathrm{v})$ poor households obtain a relatively small part of their income directly on the market, and rely more upon welfare receipts and income in kind.

According to the last two observations, two recommendations might be made for an improvement of the plight of the poorest households. Firstly, considering the well-targeted social transfers (unemployment, sick leave and child benefits and welfare assistance) towards the poor, it can be expected that an increase in the amount of such transfers would contribute to an increase in the income of the poorest, and hence to the reduction in inequality. Secondly, the exclusion of the poor from the labour market is one of the causes of their poor material conditions, so that an increase in the opportunities for work and increased employability of this group of citizens would be effective measures for the poverty reduction.

For a more precise formulation of a policy aimed at reducing unnecessary inequality and poverty reduction a well-structured research is required. One of the problems that can be met with here is the statistical base that for the moment does not facilitate sufficiently precise monitoring of the impact of measures taken within economic and social policies. The Household Budget Survey is designed to satisfy several statistical requirements: (i) provision of data about household expenditure in order to define weights for the consumer price index; (ii) monitoring of household expenditure for the purpose of industrial branch statistics (for example, tourist expenditure); (iii) assessment of personal spending for the needs of national accounts statistics and (iv) calculation of social indicators. It has to be seen that a lot is being expected of a single survey. Because of a number of purposes, the Survey has grown considerably in terms of size and the time needed to complete it, and its administration is very demanding and expensive. Similarly, precise measurement of changes year by year is limited by the nature of the survey, which is actually designed in such a way as to give periodic snapshots, not a reliable time series.

For statistical requirements that are so diverse it would be desirable to have numbers of different surveys. For the purpose of calculating social indicators it would be a good idea to have a panel survey, in which the same household would be monitored several years running. This would improve the temporal comparability of the indicators of inequality and poverty, and enable an insight into the social mobility of the population. Thus it would be possible to track which segments of the population are improving their material situation, and who the losers are, how much poverty is rooted (how long people stay in poverty) and which mechanisms give better results in the fight against poverty. The design of such a survey should be related to EU experience, but could be supplemented with questions important for the purpose of managing domestic economic and social policies. In the EU, the EU-SILC (European Statistics on Income and Living Conditions) panel survey is being developed rapidly; many EU members have carried out pilot projects, and in 2005 - 2006 it is expected to be fully introduced into most of the member states. Hence it would seem necessary in Croatia too to undertake measures for the swift introduction of such a survey, adjusted to take account of both European statistical standards and domestic policy purposes. 


\section{REFERENCES:}

Cowell, F. A., 1995. Measuring Inequality. London: Prentice Hall: Harvester Wheatsheaf.

DZS, 1998. Anketa o potrošnji kućanstava 1998. Baza podataka Državnog zavoda za statistiku Republike Hrvatske.

DZS, 1999. Anketa o potrošnji kućanstava 1999 - ukupno raspoloživa sredstva kućanstva po decilima. Neobjavljene radne tablice Državnog zavoda za statistiku Republike Hrvatske.

DZS, 2000. Anketa o potrošnji kućanstava 2000 - ukupno raspoloživa sredstva kućanstva po decilima prosjek po članu kućanstva. Neobjavljene radne tablice Državnog zavoda za statistiku Republike Hrvatske.

DZS, 2001. Anketa o potrošnji kućanstava 2001 - ukupno raspoloživa sredstva kućanstva po decilima prosjek po članu kućanstva. Neobjavljene radne tablice Državnog zavoda za statistiku Republike Hrvatske.

DZS, 2002. Anketa o potrošnji kućanstava 2002 - ukupno raspoloživa sredstva kućanstva po decilima prosjek po članu kućanstva. Neobjavljene radne tablice Državnog zavoda za statistiku Republike Hrvatske.

DZS, 2003a. "Anketa o potrošnji kućanstava - osnovne karakteristike potrošnje i primanja kućanstava od 2000. do 2002." Priopćenje, (13.2.1). Zagreb: Državni zavod za statistiku.

DZS, 2003b. Statistički ljetopis 2003. Zagreb: Držani zavod za statistiku.

DZS, 2004. «Pokazatelji siromaštva od 2001. do 2003.” Priopćenje, (13.2.2). Zagreb: Državni zavod za statistiku.

Fei, J. C. H., Ranis, G. and Kuo, S. W. Y., 1978. "Growth and family distribution of income by factor components". Quarterly Journal of Economics, (92), 17-53.

Nestić, D., 2002. “Ekonomske nejednakosti u Hrvatskoj 1973-1998”. Financijska teorija i praksa, 26 (3), 595-613.

SZS, 1990. «Anketa o potrošnji domaćinstava u 1988. - raspoloživa i upotrebljena sredstva - prosek po članu domaćinstva». Statistički bilten, (1851). Beograd: Savezni zavod za statistiku.

World Bank, 2000. Croatia: Economic Vulnerability and Welfare Study, Volume II: Technical Papers. Washington D.C.: World Bank, Poverty Reduction and Economic Management Unit, Europe and Central Asia Region.

Zakon o povećanju mirovina radi uklanjanja razlika u razini mirovina ostvarenih u različitim razdobljima, NN 127/00. Zagreb: Narodne novine. 


\section{INSTITUTE OF PUBLIC FINANCE - OCCASIONAL PAPER SERIES}

No. 1 State Intervention for Growth Promotion in Market Economies

Marina Kesner Škreb, January 1997

No. 2 Estimate of Revenues from the Value Added Tax in the Republic of Croatia

Danijela Kuliš and Žarko Miljenović, October 1997

No. 3 The Unofficial Economy in Croatia: Causes, Size and Consequences

Ivo Bićanić and Katarina Ott, November 1997

No. 4 Price Effects of VAT Introduction in Croatia

Martina Dalić, December 1997

No. 5 Tax Administration Reform in Transition: The Case of Croatia

Katarina Ott, April 1998

No. 6 The Present Sate of the Croatian Public Debt

Zoran Bubaš, December 1998

No. 7 Public Investment in Croatia

Katarina Ott and Anto Bajo, March 1999.

No. 8 Welfare Policy and Social Transfers in Croatia

Predrag Bejaković and Alastair McAuley, July 1999

No. 9 Is Unofficial Economy a Source of Corruption?

Vedran Šošić and Michael Faulend, November 1999

No. 10 Banking Sector Problems: Causes, Resolutions and Consequences

Ljubinko Jankov, March 2000

No. 11 Toward a Long - Term Strategy of Economic Development of Croatia: Where to Begin, What to Do, and How to Do It?

Dubravko Mihaljek, June 2001

No. 12 The Underground Economy in Croatia

Katarina Ott, March 2002

No. 13 An Estimate of the Extent of Tax Evasion in Croatia

Sanja Madžarević Šujster, April 2002

No. 14 Opportunism, Institutions and Moral Costs: The Socio - Cultural Dimension of the Underground Economy in Croatia 1995 - 1999

Aleksandar Štulhofer and Ivan Rimac, April 2002

No. 15 Dollarisation and the Underground Economy: Accidental Partners?

Vedran Šošić and Michael Faulend, April 2002 
No. 16 Decentralization in the Republic of Croatia - A City Budget in the Period from 1996 to 2000

Mihaela Pitarević, March 2003

No. 17 Inequality in Croatia in the Period from 1973 to 1998

Danijeli Nestić, April 2003

No. 18 State Aid to Enterprises in Croatia in 2001

Marina Kesner-Škreb, Ivana Pleše and Mia Mikić, October 2003

No. 19 The Role of Parliament in the Budgetary Process - The Example of the Croatian Parliament (2000-2003)

Vjekoslav Bratić, October 2004

No. 20 Local Government Unit Borrowing in Croatia: Opportunities and Constraints Anto Bajo, October 2004

No. 21 The Costs of Customs Compliance in Croatia in 2001

Mihaela Bronić, November 2004

No. 22 Tax Compliance Costs of Small Business in Croatia

Helena Blažić, November 2004

No. 23 The Compliance Costs of Excise Duties in Croatia

Danijela Kuliš, November 2004

No. 24 The Administrative Costs of Taxation and Customs Clearing in Croatia, 1999-2001 Vjekoslav Bratić and Mihaela Bronić, November 2004

No. 25 Fiscal Decentralisation in Croatia - Problems of Fiscal Equalisation Anto Bajo and Mihaela Bronić, May 2005

No. 26 Income Distribution in Croatia: What do the Household Budget Survey Data Tell Us? Danijel Nestić, June 2005 


\section{ABOUT THE INSTITUTE OF PUBLIC FINANCE}

The Institute of Public Finance, founded in 1970, is a public institution dealing with research into primarily economic topics important for economic growth and development, transition to the market economy and meeting the requirements for European integration.

Under the general aegis of the public sector economics, topics such as transparency, accountability and participation, the tax system, costs of taxation, progressiveness of taxation, fiscal federalism, the pensions system and welfare system, public debt, the unofficial economy, state aid, foreign direct investment, the financing of science and higher education, and the relations between the executive branch and the legislature in the budgetary process are subjected to ongoing investigation.

\section{SELECTED LIST OF PUBLICATION (in English)}

\section{Serial publications}

- Financial Theory and Practice

- Occasional Paper Series

- Newsletter

\section{Books}

- Croatian Accession to the European Union: Facing the Challenges of Negotiations, editor Katarina Ott, 2005.

- Croatian Income Tax\&Profit Tax, editors Marina Kesner-Škreb and Danijela Kuliš, 2005.

- The competitiveness of Croatia's human resources, editors Predrag Bejaković and Joseph Lowther, 2004.

- Croatian Accession to the European Union: Institutional Challenges, editor Katarina Ott, 2004.

- The Croatian Tax System, editor Mirjana Jerković, 2003.

- Croatian Accession to the European Union: Economic and Legal Challenges, editor Katarina Ott, 2003.

- The Citizen's Guide to Taxation, Marina Kesner-Škreb and Danijela Kuliš, 2001, (updated online).

- A Citizen's Guide to the Budget, editor Katarina Ott, 2000.

For further insight in our publications and ordering information please visit:

http://www.ijf.hr/eng/index.html. 